Article

\title{
Influence of carbon and yttrium co-doping on the photocatalytic activity of mixed phase $\mathrm{TiO}_{2}$
}

\author{
Honglin Gao, Jianmei Liu, Jin Zhang, Zhongqi Zhu, Genlin Zhang, Qingju Liu* \\ School of Materials Science and Engineering, Yunnan Key Laboratory for Micro/nano Materials \& Technology, Yunnan University, Kunming 650091, \\ Yunnan, China
}

\section{A R T I C L E I N F O}

\section{Article history:}

Received 31 May 2017

Accepted 30 July 2017

Published 5 October 2017

\section{Keywords:}

Titanium dioxide

Co-doping

Mixed phase

Phase control

Visible light photocatalysis

\begin{abstract}
A B S T R A C T
Mixed phase $\mathrm{TiO}_{2}$ photocatalysts doped with $\mathrm{C}$ and $\mathrm{Y}$ were synthesized by a sol-gel process. The effects of $\mathrm{C}$ and $\mathrm{Y}$ doping and annealing temperatures on the structural and optical properties, and photocatalytic activity were investigated. We found that both $\mathrm{C}$ and $\mathrm{Y}$ doping can broaden the absorption spectrum of $\mathrm{TiO}_{2}$ to the visible light region and inhibit recombination of photogenerated electron/hole pairs. The incorporation of $\mathrm{Y}$ into the $\mathrm{TiO}_{2}$ lattice inhibited growth of crystalline grains, which increased the specific surface area and enhanced the photocatalytic activity. The photocatalytic performance of the samples was investigated in the photocatalytic degradation of methyl blue under visible light irradiation. The rate of methyl blue degradation over the (C, Y)-co-doped $\mathrm{TiO}_{2}$ sample was much higher than those of undoped $\mathrm{TiO}_{2}, \mathrm{C}-\mathrm{TiO}_{2}$, and $\mathrm{Y}-\mathrm{TiO}_{2}$. Additionally, the apparent first-order rate constant of the co-doped sample was 3.5 times as large as that of undoped mix phase $\mathrm{TiO}_{2}$ under the same experimental conditions. The enhanced photocatalytic activity can be attributed to the synergic effect of (C, Y)-co-doping and the formation of an appropriate crystalline structure.
\end{abstract}

(C) 2017, Dalian Institute of Chemical Physics, Chinese Academy of Sciences. Published by Elsevier B.V. All rights reserved.

\section{Introduction}

Photodegradation of organic contaminants by semiconductor catalysts is a promising potential environmental remediation technology [1]. In particular $\mathrm{TiO}_{2}$ has attracted considerable attention owning to its good environmental compatibility, low toxicity, high photocatalytic activity, high oxidation potential, low cost, and good chemical stability. However, the band gap of anatase $\mathrm{TiO}_{2}$ is approximately $3.2 \mathrm{eV}$, meaning that only UV-light irradiation $(\lambda<387 \mathrm{~nm})$ contributes to photocatalytic activity. Thus, only a small proportion $(<5 \%)$ of solar energy can be used. Furthermore, photogenerated electron/hole pairs easily recombine, resulting in low photocatalytic efficiency [2]. The photocatalytic activity of $\mathrm{TiO}_{2}$ can be enhanced by broadening its absorption to capture more visible light and decreasing the recombination of photogenerated electron/hole pairs. In recent years, many attempts have been made to overcome the inherent weaknesses of $\mathrm{TiO}_{2}$ and improve its photocatalytic efficiency, including ion doping [3,4], noble metal deposition [5], formation of semiconductor composites [6], and dye sensitizing [7]. Generally, ion doping is considered to be a simple and effective modification method, including doping of metal and non-metal ions [8].

Dopants form impurity levels in the forbidden band gap,

\footnotetext{
* Corresponding author. Tel/Fax: +86-871-65035376; E-mail: qjliu@ynu.edu.cn

This work was supported by the National High Technology Research and Development Program of China (863 Program, 2015AA034601), the Natural Science Foundation of Yunnan Province (2016FB084), the Scientific Research Foundation of the Department of Education of Yunnan Province (2015Z003), and the Open Fund of Yunnan Key Laboratory for Micro/nano Materials \& Technology (ZZ2016006).

DOI: 10.1016/S1872-2067(17)62893-6 | http://www.sciencedirect.com/science/journal/18722067 | Chin. J. Catal., Vol. 38, No. 10, October 2017
} 
resulting in a red shift of the light absorption spectrum and/or inhibition of carrier recombination in $\mathrm{TiO}_{2}$. Carbon doping of $\mathrm{TiO}_{2}$ has been reported to improve its visible light response and photocatalytic activity [9-12]. Rare earth ions are also considered to be an effective dopant for modifying the crystal structure, electronic structure, and optical properties of $\mathrm{TiO}_{2}$ [13]. In particular, Y-ion doping of $\mathrm{TiO}_{2}$ has been found to decrease the recombination rate of photogenerated electron/hole pairs, which improved the photocatalytic efficiency of $\mathrm{TiO}_{2}$ [14]. The photocatalytic activity of $\mathrm{TiO}_{2}$ co-doped with multiple ions is often better than that of $\mathrm{TiO}_{2}$ doped with a single type of ion because of synergic effects of the co-doped ions [15]. Although there have been many reports on non-metal and rare earth metal ions doped $\mathrm{TiO}_{2}$ [16], there have been few reports on carbon and yttrium co-doped $\mathrm{TiO}_{2}$.

Additionally, it has been shown that appropriate proportions of anatase and rutile phases can enhance photocatalytic activity of $\mathrm{TiO}_{2}$. The rate of photogenerated electron-hole pair separation and charge migration can be enhanced in $\mathrm{TiO}_{2}$ owing to the formation of heterostructures [17-19]. It is possible to improve the photocatalytic activity by controlling the proportion of anatase and rutile phases in $\mathrm{TiO}_{2}$ with various methods. Some researchers have experimentally demonstrated that the different Fermi levels of the rutile and anatase phases, and the interfaces between their particles affect spatial charge migration [20-22].

In this study, we prepared C-, Y-co-doped mixed phase $\mathrm{TiO}_{2}$, undoped $\mathrm{TiO}_{2}, \mathrm{C}-\mathrm{TiO}_{2}$, and $\mathrm{Y}^{-\mathrm{TiO}_{2}}$ samples through a sol-gel process. A comprehensive study of the (C, Y)-co-doped $\mathrm{TiO}_{2}$ with a mixture of anatase and rutile phases was performed. The samples were characterized by X-ray diffraction (XRD), transmission electron microscope (TEM) imaging, X-ray photo electron spectroscopy (XPS), Raman spectroscopy, photoluminescence (PL) spectroscopy, and UV-Vis diffuse reflectance spectroscopy (DRS). The photocatalytic activity of the (C, Y)-codoped $\mathrm{TiO}_{2}$ sample was examined for its decomposition of methylene blue (MB) under visible light irradiation. These results were compared with those from undoped $\mathrm{TiO}_{2}, \mathrm{C}-\mathrm{TiO}_{2}$, and $\mathrm{Y}-\mathrm{TiO}_{2}$ samples, which are commonly used as a reference in photocatalytic reactions. The aim of this study was to develop an understanding of how dopants and the ratio of anatase and rutile phases affect the photocatalytic activity and intrinsic properties of $\mathrm{TiO}_{2}$.

\section{Experimental}

\subsection{Materials}

Tetra- $n$-butyl titanate $\left(\mathrm{Ti}\left(\mathrm{OC}_{4} \mathrm{H}_{9}\right)_{4}, 98 \%, \mathrm{CP}\right)$ was supplied by Shanghai Runjie Chemical Reagent Company, China. Yttrium nitrate $\left(\mathrm{Y}\left(\mathrm{NO}_{3}\right)_{3} \cdot 6 \mathrm{H}_{2} \mathrm{O}, 99 \%\right.$, AP) and nitric acid $\left(\mathrm{HNO}_{3}, 99 \%\right.$, AP) were purchased from Shantou Xilong Chemical Factory, Guangdong Province, China. Glucose $\left(\mathrm{C}_{6} \mathrm{H}_{12} \mathrm{O}_{6}, 99 \%\right.$, AP) was obtained from Tianjin Fengchuan Chemical Reagent Technologies Co., Ltd, China. The hydrolysis inhibitor was made in our laboratory. All reagents were used as received without further purification. Deionized water was used throughout the experi- ments.

\subsection{Preparation of photocatalyst nanoparticles}

The $\mathrm{C}, \mathrm{Y}$ co-doped $\mathrm{TiO}_{2}$ was prepared by a sol-gel method followed by calcination. In a typical synthesis, appropriate amounts of $\mathrm{C}_{6} \mathrm{H}_{12} \mathrm{O}_{6}(\mathrm{C} / \mathrm{Ti}=0.3)$ and $\mathrm{Y}\left(\mathrm{NO}_{3}\right)_{3} \cdot 6 \mathrm{H}_{2} \mathrm{O}$ were completely dissolved in $5 \mathrm{~mL}$ of distilled water to form solution $\mathrm{A}$. A 5-mL portion of $\mathrm{Ti}\left(\mathrm{OC}_{4} \mathrm{H}_{9}\right)_{4}$ was slowly added to $75 \mathrm{~mL}$ of distilled water, which included $3 \mathrm{~mL}$ of the hydrolysis inhibitor, under strong stirring at $60^{\circ} \mathrm{C}$. The $\mathrm{pH}$ value was adjusted to 2.0 by the addition of $2.5 \mathrm{~mol} / \mathrm{L} \mathrm{HNO}_{3}$ to form a milky suspension. Solution A was then added to the suspension and a uniform yellow sol formed under continuous stirring at $60^{\circ} \mathrm{C}$ for $15 \mathrm{~h}$. Subsequently, the mixture was aged for $24 \mathrm{~h}$, dried at $80^{\circ} \mathrm{C}$ in air, ground, and sintered at $500^{\circ} \mathrm{C}$ in air for $4 \mathrm{~h}$ to obtain the $\mathrm{C}-\mathrm{Y}-\mathrm{TiO}_{2}$ photocatalysts. The nominal $\mathrm{Y}^{3+}$ doping levels in the co-doped $\mathrm{TiO}_{2}$ samples were $0.2 \%, 0.3 \%, 0.4 \%, 0.5 \%$, and $0.6 \%$, respectively. For comparison, pure $\mathrm{TiO}_{2}$, and $\mathrm{C}$ - and Y-mono-doped $\mathrm{TiO}_{2}$ samples were also prepared by similar procedures.

\subsection{Characterization of nanoparticles}

XRD patterns were measured on a Rigaku-TTRIII diffractometer with the use of a $\mathrm{Cu} K_{\alpha}$ radiation $(\lambda=0.15406 \AA)$ source at an operating voltage of $40 \mathrm{kV}$ and a current of 150 $\mathrm{mA}$. The particle morphologies of the samples were examined with a TEM (JEM-2100) operating at an accelerating voltage of $150 \mathrm{kV}$. The XPS measurements of the samples were performed on a PHI-5500 Versa Probe II. Photoelectrons emitted perpendicular to the sample surface were collected. The binding energies of all investigated elements were referenced to the $\mathrm{C} 1 \mathrm{~s}$ peak at $284.6 \mathrm{eV}$ from adventitious surface carbon. Raman analysis was performed on an In-Via Raman spectrometer with a high-power near-infrared (Near-IR) diode laser $(\lambda=785 \mathrm{~nm}$, $0.2 \mathrm{~mW}$ ) as the excitation source. The DRS of the samples were measured on a UV-Vis spectrophotometer (UV-2401PC, Shimadzu), with $\mathrm{BaSO}_{4}$ as a reference standard and were converted to the absorbance data by the Kubelka-Munk method. Photoluminescence emission (PL, FL4500) spectra of samples were measured to investigate recombination of photogenerated electron/hole pairs.

\subsection{Photocatalytic activity of nanoparticles}

The photocatalytic activity of the samples was measured by examining the photodegradation of methylene blue (MB) in an aqueous solution under a $30 \mathrm{~W}$ fluorescent lamp. A set of photocatalytic degradation experiments was performed as follows. $0.1 \mathrm{~g}$ of photocatalyst was suspended in $50 \mathrm{~mL}$ MB solution (10 $\mathrm{mg} / \mathrm{L}$ ) with magnetic stirring. The mixture was kept in dark for $30 \mathrm{~min}$ to ensure a complete adsorption-desorption equilibrium before illumination. At certain time intervals ( $30 \mathrm{~min}$ ), $4 \mathrm{~mL}$ of the suspension was removed and centrifuged at $3500 \mathrm{r} / \mathrm{min}$. The absorption of MB in the aqueous solution at $664 \mathrm{~nm}$ was measured with a JH722N UV-Vis spectrophotometer. The pho- 
todegradation efficiency of MB in the solution was determined by the following formula:

$$
\eta=\left(C_{0}-C\right) / C_{0} \times 100 \%
$$

where $\eta$ is the degradation rate, $C$ is the remaining MB concentration, and $C_{0}$ is the initial $\mathrm{MB}$ concentration before irradiation.

The kinetics of the MB photodegradation on the $\mathrm{TiO}_{2}$ surface could be described by the pseudo-first-order reaction kinetics equation:

$$
\ln \left(C_{0} / C\right)=k t
$$

where $C_{0}$ is the initial concentration of $\mathrm{MB}$, and $C$ is the actual concentration of MB after light irradiation time $t$. The pseudo-first-order rate constants $(k)$ were calculated by linear fitting of the experimental data, and used to compare the photocatalytic activity of the catalysts.

\section{Results and discussion}

\subsection{Characterization of mixed phase $\mathrm{TiO}_{2}$}

Typical XRD patterns of the as-prepared samples are presented in Fig. 1. Strong diffraction peaks of the samples indicated the high crystallinity of the samples. The diffraction peaks were indexed to anatase (JCPDS No. 21-1272) and rutile (JCPDS No. 88-1175) phases of $\mathrm{TiO}_{2}$. The anatase peaks are labeled as (101), (004), (200), (211), and (204) planes; the rutile peaks are labeled as (110), (101), (111), (211), (220), and (301) planes. No yttrium oxide-related diffraction peaks were detected in any of samples. This is likely because of the high dispersion and the low content of the doping elements, $\mathrm{C}$ and $\mathrm{Y}$ [23]. Table 1 shows the anatase phase content and the average crystallite size of the samples, as calculated by the Spurr and Myers and Debye-Scherrer formulae, respectively. All samples that were sintered at $500{ }^{\circ} \mathrm{C}$ featured both anatase and rutile phases. The content of the anatase phase was low in the $\mathrm{C}-\mathrm{TiO}_{2}$ sample at only 8.34\%; However, the anatase phase made up

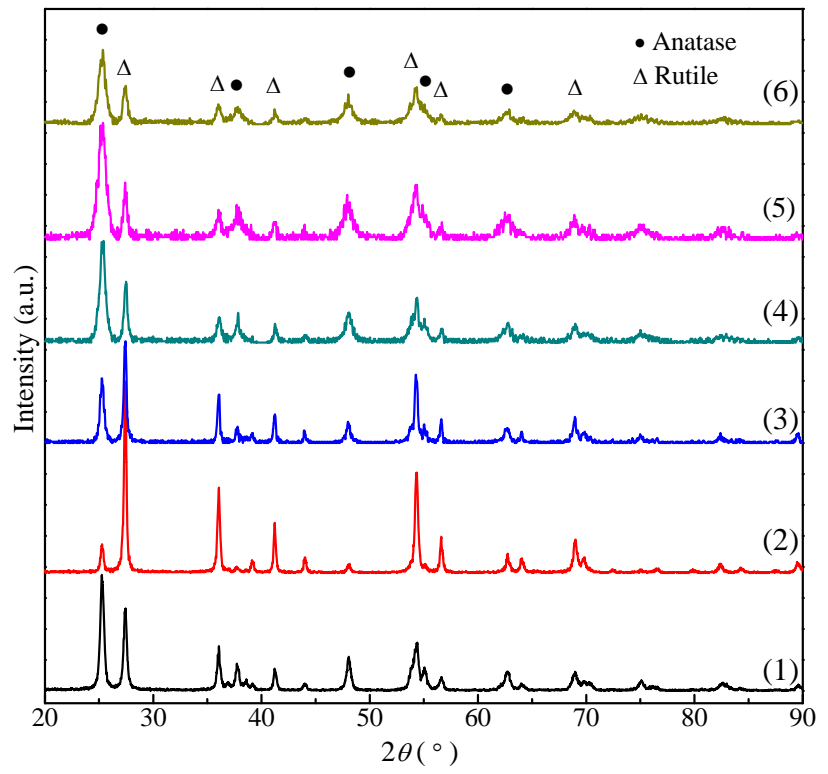

Fig. 1. XRD patterns for pure (1), C-doped (2), Y-doped (6) and (C, Y)-co-doped $\mathrm{TiO}_{2}$ with Y-doping levels of $0.2 \%$ (3), $0.4 \%$ (4), and $0.6 \%$ (5). All samples were sintered at $500{ }^{\circ} \mathrm{C}$.
Table 1

Anatase content and crystalline size of samples sintered at $500{ }^{\circ} \mathrm{C}$.

\begin{tabular}{lcc}
\hline Sample & $\begin{array}{c}\text { Content of anatase } \\
\text { phase }(\%)\end{array}$ & $\begin{array}{c}\text { Average crystalline } \\
\text { size }(\mathrm{nm})\end{array}$ \\
\hline Pure $\mathrm{TiO}_{2}$ & 62.17 & 21.33 \\
$\mathrm{C}^{-\mathrm{TiO}_{2}}(\mathrm{C} / \mathrm{Ti}=30 \%)$ & 8.34 & 34.41 \\
$\mathrm{Y}^{-\mathrm{TiO}_{2}}(\mathrm{Y} / \mathrm{Ti}=0.4 \%)$ & 69.20 & 12.60 \\
$\mathrm{C}-\mathrm{Y}-\mathrm{TiO}_{2}(\mathrm{Y} / \mathrm{Ti}=0.2 \%)$ & 39.31 & 15.68 \\
$\mathrm{C}-\mathrm{Y}-\mathrm{TiO}_{2}(\mathrm{Y} / \mathrm{Ti}=0.4 \%)$ & 68.42 & 10.65 \\
$\mathrm{C}-\mathrm{Y}-\mathrm{TiO}_{2}(\mathrm{Y} / \mathrm{Ti}=0.6 \%)$ & 76.21 & 5.01 \\
\hline
\end{tabular}

$69.20 \%$ of the $\mathrm{Y}^{-\mathrm{TiO}_{2}}$ sample and $68.42 \%$ of the $\mathrm{C}-\mathrm{Y}-\mathrm{TiO}_{2}$ sample. Doping with $\mathrm{C}$ can promote the $\mathrm{TiO}_{2}$ phase transition from anatase to rutile, while $\mathrm{Y}$ doping inhibits the transformation. Doping of single elements into the $\mathrm{TiO}_{2}$ lattice can have different effects on the phase transition behavior; however, these effects were markedly different in the $(\mathrm{C}, \mathrm{Y})$-co-doped $\mathrm{TiO}_{2}$.

The results shown in Table 1 indicate that when sintered at $500{ }^{\circ} \mathrm{C}$, the average size of crystallites in $\mathrm{C}-\mathrm{Y}-\mathrm{TiO}_{2}, \mathrm{C}-\mathrm{TiO}_{2}$, $\mathrm{Y}-\mathrm{TiO}_{2}$, and pure $\mathrm{TiO}_{2}$ were $10.65,34.41,12.60$, and $21.33 \mathrm{~nm}$, respectively. Thus, $\mathrm{C}$ - and $\mathrm{Y}$-co-doping can decrease the size of individual $\mathrm{TiO}_{2}$ crystallites. The effects of the doping elements on the phase transformation behavior and grain growth can be explained as follows. First, the attraction of anions toward Ti cations plays an important role in the phase transformation; a weaker attraction of the ions toward Ti enables a more facile rearrangement of $\mathrm{TiO}_{6}$ octahedral units [9]. Thus, the weaker attraction of $\mathrm{C}$ ions promotes structural rearrangements and phase transformations. Second, carbon can act as a nucleation seed in the calcination process and enhance the crystallization and phase transformation [24]. Third, the growth process can be considered in terms of the balance of interfacial and bulk energies. Furthermore, the presence of $\mathrm{Y}$ ions might form a $\mathrm{Y}_{2} \mathrm{O}_{3}$ layer that could alter this energy balance of $\mathrm{TiO}_{2}$ crystallites to limit their growth. Thus, the low average crystalline size of the $(\mathrm{C}, \mathrm{Y})$-co-doped $\mathrm{TiO}_{2}$ can be attributed to a combination of effects from $\mathrm{C}$ and $\mathrm{Y}$ ions [25]. We measured the actual Y-doping content by energy-dispersive X-ray spectroscopy and these results were consistent with the amount of $Y$ added during synthesis.

Raman spectroscopy is known to be a sensitive and widely used method for detecting phase changes and the presence of nano-oxide clusters. Undoped $\mathrm{TiO}_{2}$ and doped $\mathrm{TiO}_{2}$ samples, sintered at $500^{\circ} \mathrm{C}$, were characterized by Raman spectroscopy (Fig. 2). The results of Raman analysis were consistent with the XRD results in that all samples contained polymorphic $\mathrm{TiO}_{2}$ $[26,27]$. The phase content (anatase and rutile) varied with the synthesis conditions. The Raman peaks at $144 \mathrm{~cm}^{-1}\left(E_{\mathrm{g}}\right), 198$ $\mathrm{cm}^{-1}\left(E_{\mathrm{g}}\right), 397 \mathrm{~cm}^{-1}\left(B_{1 \mathrm{~g}}\right), 516 \mathrm{~cm}^{-1}\left(A_{1 \mathrm{~g}}\right.$ and $\left.B_{1 \mathrm{~g}}\right)$, and $639 \mathrm{~cm}^{-1}$ $\left(E_{\mathrm{g}}\right)$ could be assigned to the anatase phase [28]; peaks at 449 $\mathrm{cm}^{-1}\left(E_{\mathrm{g}}\right)$ and $610 \mathrm{~cm}^{-1}\left(A_{1 \mathrm{~g}}\right)$ were assigned to the rutile phase [29]. The Raman peaks of all samples were identified as either anatase or rutile, with no yttrium oxide peaks. This observation agrees with the absence of yttrium oxide diffraction lines in the XRD spectra and thus confirmed that lattice substitution occurred. To investigate the effects of $\mathrm{C}$ - and Y-doping on the phase structure of $\mathrm{TiO}_{2}$, the main $E_{\mathrm{g}}$ Raman modes of anatase 

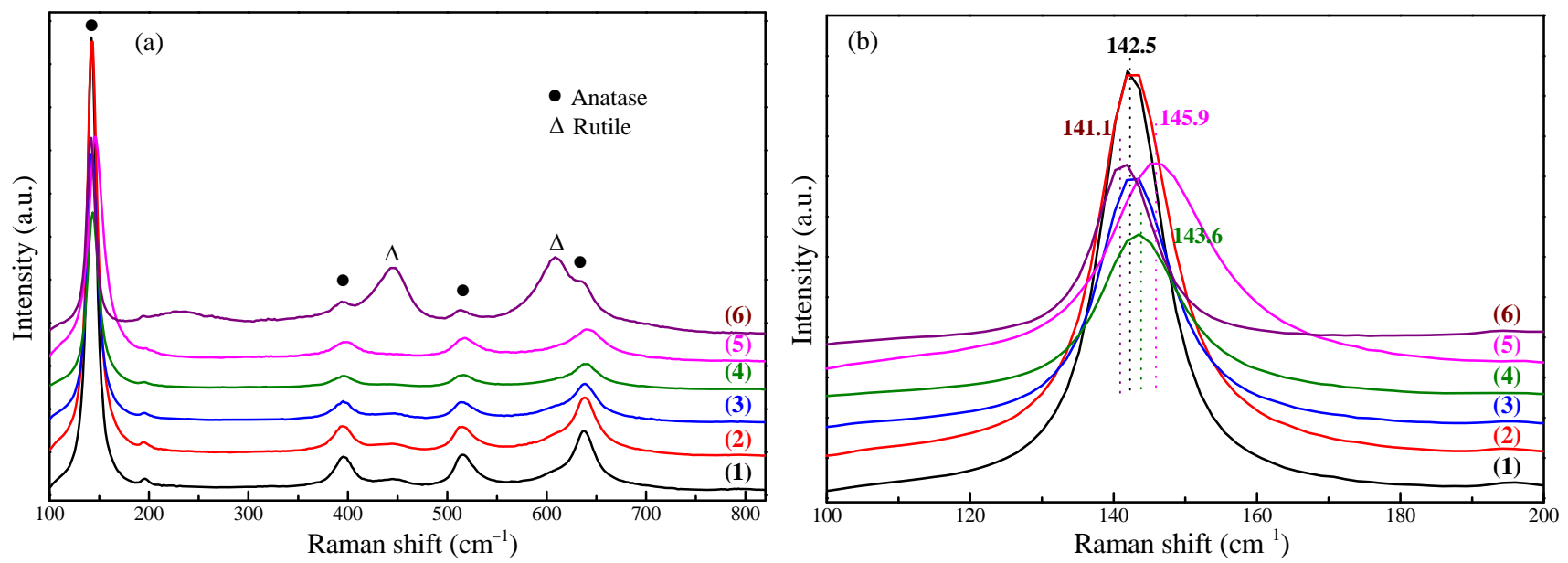

Fig. 2. Raman spectra (a) and the main anatase Raman $E_{\mathrm{g}}$ peak (b) of the samples. (1) Pure $\mathrm{TiO}_{2}$; (C, Y)-co-doped $\mathrm{TiO}_{2}$ with $\mathrm{Y}$-doping levels of $0.2 \%$ (2) $0.4 \%$ (3), and $0.6 \%$ (4); (5) Y-doped $\mathrm{TiO}_{2}$; (6) C-doped $\mathrm{TiO}_{2}$. All samples were sintered at $500{ }^{\circ} \mathrm{C}$.

$\mathrm{TiO}_{2}$ were considered. As shown in Fig. 2(b), the frequency and relative intensity of the $E_{\mathrm{g}}$ Raman mode strongly depended on the doped atom type and content. The main $E_{\mathrm{g}}$ peak of the $\mathrm{TiO}_{2}$ nanoparticles shifted to low wavenumber (i.e., red shifted) with C-doping. The peaks blue shifted with increasing Y doping. In the co-doped samples, as the content of $Y$ was increased, the intensity of the $E_{\mathrm{g}}$ mode decreased, accompanied by a red shift. Larger crystallite sizes would be expected to have sharper and more blue-shifted Raman peaks, owing to confinement effects [30-32]. Thus, the different elements doped into the $\mathrm{TiO}_{2}$ lattice affected the crystallite size and the formation and transformation of anatase-rutile phases.

\subsection{TEM studies}

To gain further understanding of the morphology and microstructure of the (C, Y)-co-doped $\mathrm{TiO}_{2}$, TEM and selected area electron diffraction (SAED) images of a (C, Y)-co-doped $\mathrm{TiO}_{2}$ sample, sintered at $500{ }^{\circ} \mathrm{C}$, are shown in Fig. 3. Only anatase and rutile phases were observed in high magnification images of the sample, consistent with our XRD results. Fig. 3(a) shows an image of the particle distribution. Nanoparticles aggregated and formed cluster structures owing to the surface charge distribution and adsorption effects. The SAED (in the inset of Fig. 3(a)) clearly showed concentric Debye-Scherrer rings, which could be indexed to the (101), (004), and (105) planes of anatase $\mathrm{TiO}_{2}$. These results also confirmed the presence of a large number of randomly oriented crystallites in this domain. Some diffraction points in the SAED pattern corresponded to the (110), (101), and (111) lattice planes of the rutile phase. These observations confirmed that the rutile phase had a higher degree of crystallinity than that of the anatase phase in the $\mathrm{TiO}_{2}$ nanoparticles. From the HRTEM image of the (C, Y)-co-doped $\mathrm{TiO}_{2}$ nanoparticles (Fig. 3(b)), the spacings of the established lattice fringes were observed to be $0.352,0.236$, and $0.325 \mathrm{~nm}$, which could be indexed to tetragonal anatase $\left(d_{101}=0.35\right.$ and $\left.d_{004}=0.24 \mathrm{~nm}\right)$ and rutile $\left(d_{110}=0.32 \mathrm{~nm}\right)$ phases. This finding further confirmed the mixed phase composition of the co-doped $\mathrm{TiO}_{2}$ nanoparticles.

\subsection{XPS measurements}

XPS analysis was performed to examine the surface chemical states and content of foreign dopants and intrinsic ions in

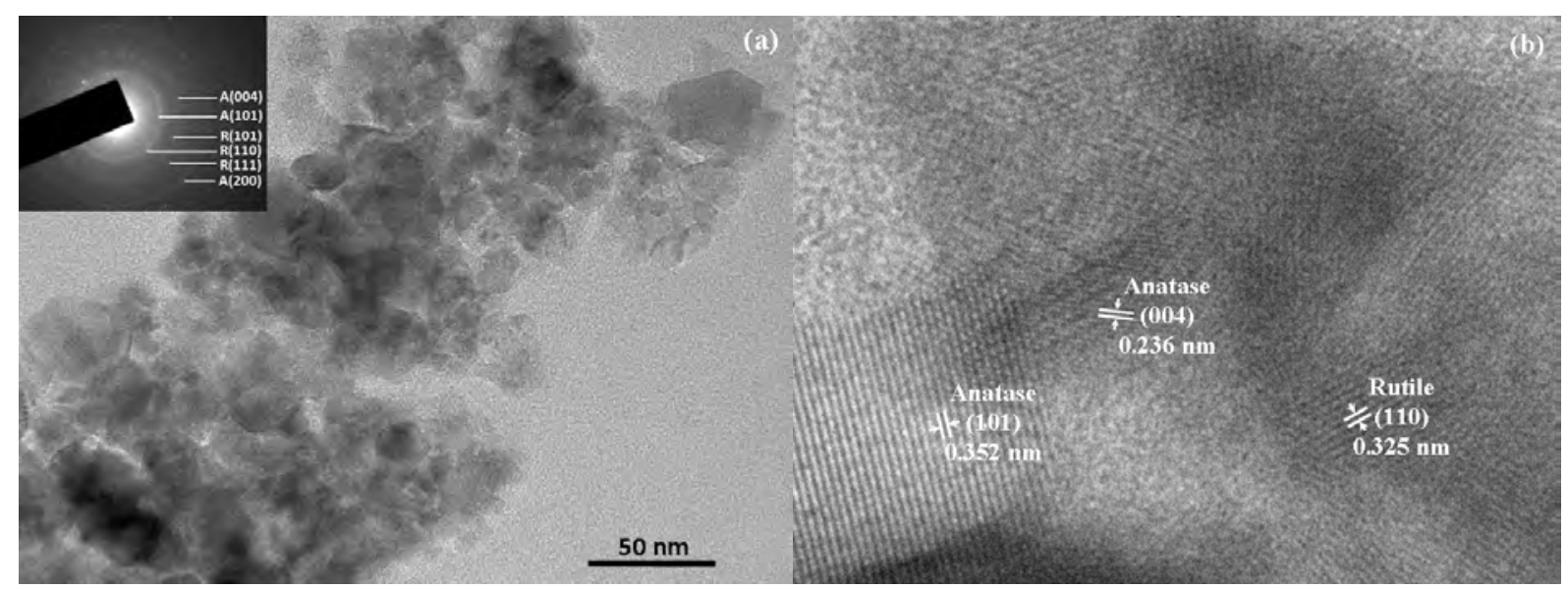

Fig. 3. TEM (a) and HRTEM (b) images of the (C, Y)-co-doped $\mathrm{TiO}_{2}$ sample. Inset in (a) shows SAED pattern of the particles. 

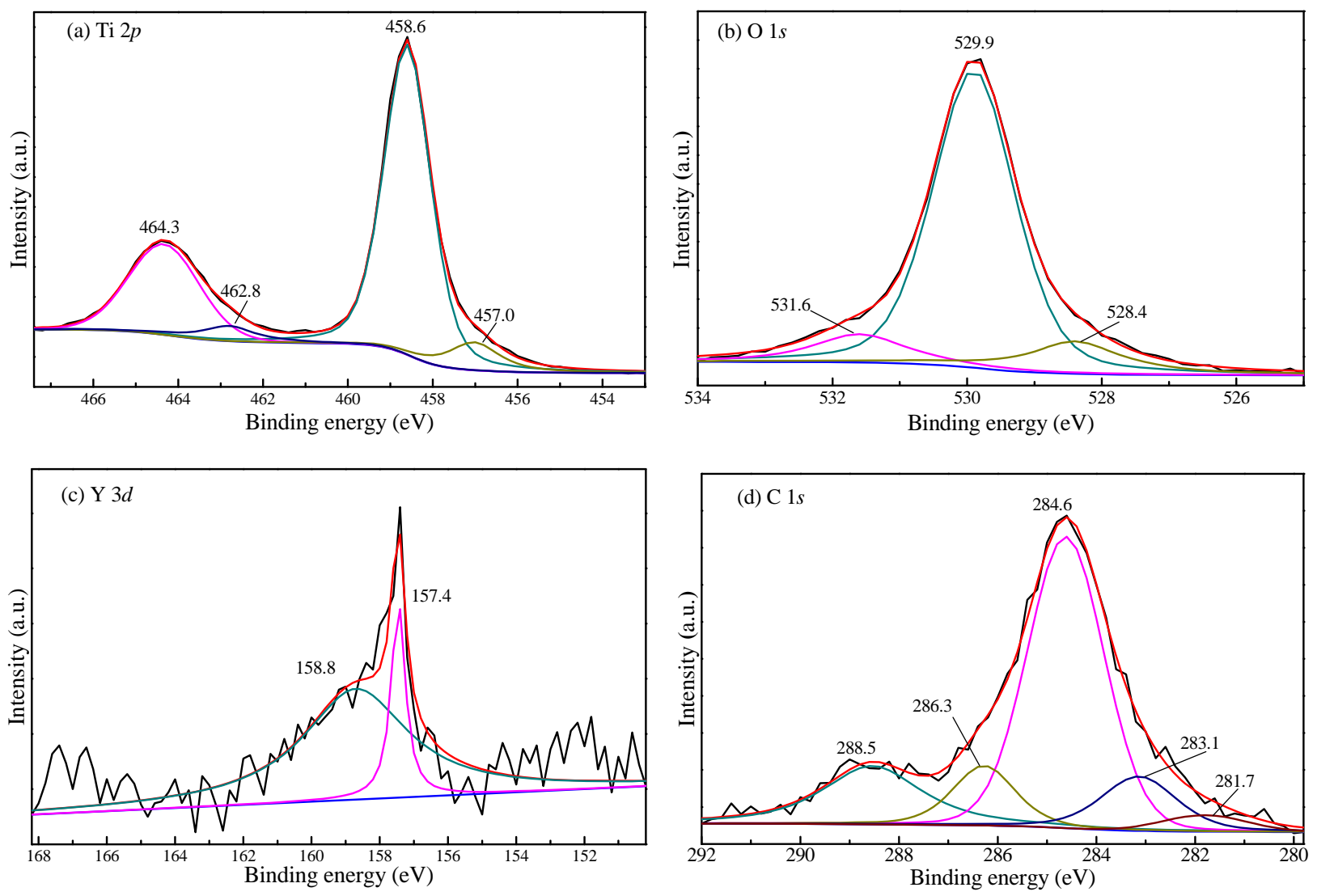

Fig. 4. High-resolution XPS spectra of the (C, Y)-co-doped $\mathrm{TiO}_{2}$ sample. (a) Ti 2p; (b) $01 s$; (c) Y 3d; (d) C $1 s$.

the co-doped sample, which was sintered at $500{ }^{\circ} \mathrm{C}$. We found that the surface of the $(\mathrm{C}, \mathrm{Y})$-co-doped $\mathrm{TiO}_{2}$ sample was composed of $\mathrm{C}, \mathrm{Ti}, \mathrm{O}$, and Y. Fig. 4 shows high-resolution $\mathrm{C} 1 s, \mathrm{Y} 3 d$, Ti $2 p$ and $01 s$ XPS spectra. In the high-resolution Ti $2 p$ XPS spectrum (Fig. $4(\mathrm{a})$ ), the $\mathrm{Ti} 2 p_{3 / 2}$ peak of (C, Y)-co-doped $\mathrm{TiO}_{2}$ was at $458.6 \mathrm{eV}$ and the Ti $2 p_{2 / 1}$ peak occurred at $464.3 \mathrm{eV}$. These peaks were attributed to $\mathrm{Ti}^{4+}$ and were similar to those of P25 (Ti $2 p_{3 / 2} 458.5 \mathrm{eV}$ and Ti $2 p_{1 / 2} 464.2 \mathrm{eV}$ ). Two low-intensity peaks of lower binding energy at 457 and $462.8 \mathrm{eV}$, corresponding to the $\mathrm{Ti}^{3+}$, were also observed in the sample [33]. As shown in Fig. 4(b), the $01 s$ high-resolution XPS spectrum featured a broad peak from 528.4 to $532 \mathrm{eV}$, which could be fitted by three peaks at 528.4, 529.9, and $531.6 \mathrm{eV}$. The peak at $528.4 \mathrm{eV}$ was attributed to oxygen combined with $\mathrm{Ti}^{3+}$ in the lattice structure of $\mathrm{Ti}_{2} \mathrm{O}_{3}$ [34]. The peak at $529.9 \mathrm{eV}$ was attributed to crystal lattice oxygen (Ti-O-Ti), i.e., 0 bound with $\mathrm{Ti}^{4+}$. The peak at $531.6 \mathrm{eV}$ originated from physically adsorbed $\mathrm{H}_{2} \mathrm{O}$ or hydroxyl groups on the surface of the $\mathrm{TiO}_{2}$ [35]. The change of binding energy and Ti valence could be attributed to the variation of electron densities among the $\mathrm{C}, \mathrm{Y}$ and $\mathrm{Ti}$ ions, when integrated into $\mathrm{TiO}_{2}$ lattice. The existence of $\mathrm{Ti}^{3+}$ ions at the surface of $(\mathrm{C}, \mathrm{Y})-\mathrm{TiO}_{2}$, suggested a possible transmission channel for holes, which might enable conduction of holes from the bulk to the surface. This could enable rapid reactions with adsorbed $\mathrm{H}_{2} \mathrm{O}$ and $\mathrm{OH}^{-}$, which might increase the utilization of photo-excited electron/hole pairs and inhibit their recombination.
The high-resolution XPS spectrum of the Y $3 d$ region (Fig. 4(c)) showed peaks at 157.4 and $158.8 \mathrm{eV}$, which could be attributed to hydrated species. Thus, the doped Y ions preferentially adsorbed water to form $\mathrm{YOOH}$ and $\mathrm{Y}(\mathrm{OH})_{3}$ [36]. Owing to the low doping concentration and dispersion of $\mathrm{Y}$ in the $\mathrm{TiO}_{2}$ lattice, the characteristic peaks of $\mathrm{Y} 3 d$ were weak. The $\mathrm{C} 1 \mathrm{~s}$ peaks in the XPS spectrum (Fig. 4(d)) could be fitted by five peaks at 281.7, 283.1, 284.6, 286.3, and $288.5 \mathrm{eV}$. The three peaks, observed at 284.6, 286.3, and $288.5 \mathrm{eV}$ could be assigned to $\mathrm{C} 1 s$ of $\mathrm{C}-\mathrm{H}, \mathrm{C}-\mathrm{O}$, and $\mathrm{O}-\mathrm{C}=\mathrm{O}$ species on the surface of $\mathrm{TiO}_{2}$, respectively [37]. These peaks likely originated from calcination products of $\mathrm{C}_{6} \mathrm{H}_{12} \mathrm{O}_{6}$ or adventitious carbon. The two new peaks at 281.7 and $283.1 \mathrm{eV}$ could be attributed to carbon atoms replacing oxygen atoms in $\mathrm{TiO}_{2}$ to form $\mathrm{Ti}-\mathrm{C}$ and $\mathrm{C}-\mathrm{Ti}-\mathrm{O}$ bonds $[38,39]$. This finding indicated that $\mathrm{C}$ was incorporated into the $\mathrm{TiO}_{2}$ lattice. These XPS results were in good agreement with our other characterization results.

\subsection{UV-Vis and PL}

Fig. 5(a) shows the UV-Vis spectra of $\mathrm{C}-\mathrm{TiO}_{2}\left(M_{\mathrm{C}} / M_{\mathrm{Ti}}=0.30\right.$, composition ratio), $\mathrm{Y}^{-\mathrm{TiO}_{2}}\left(\mathrm{M}_{\mathrm{Y}} / M_{\mathrm{Ti}}=0.004\right),(\mathrm{C}, \mathrm{Y})$-co-doped $\mathrm{TiO}_{2}\left(M_{\mathrm{C}}: M_{\mathrm{Y}}: M_{\mathrm{Ti}}=0.3: 0.004: 1\right)$, and undoped $\mathrm{TiO}_{2}$. The undoped $\mathrm{TiO}_{2}$ exhibited absorption only in the UV region. The absorption spectra of the doped samples showed a clear red shift compared with that of P25. The $(\mathrm{C}, \mathrm{Y})$-co-doped $\mathrm{TiO}_{2}$ sample showed the widest absorption range and featured the strongest 

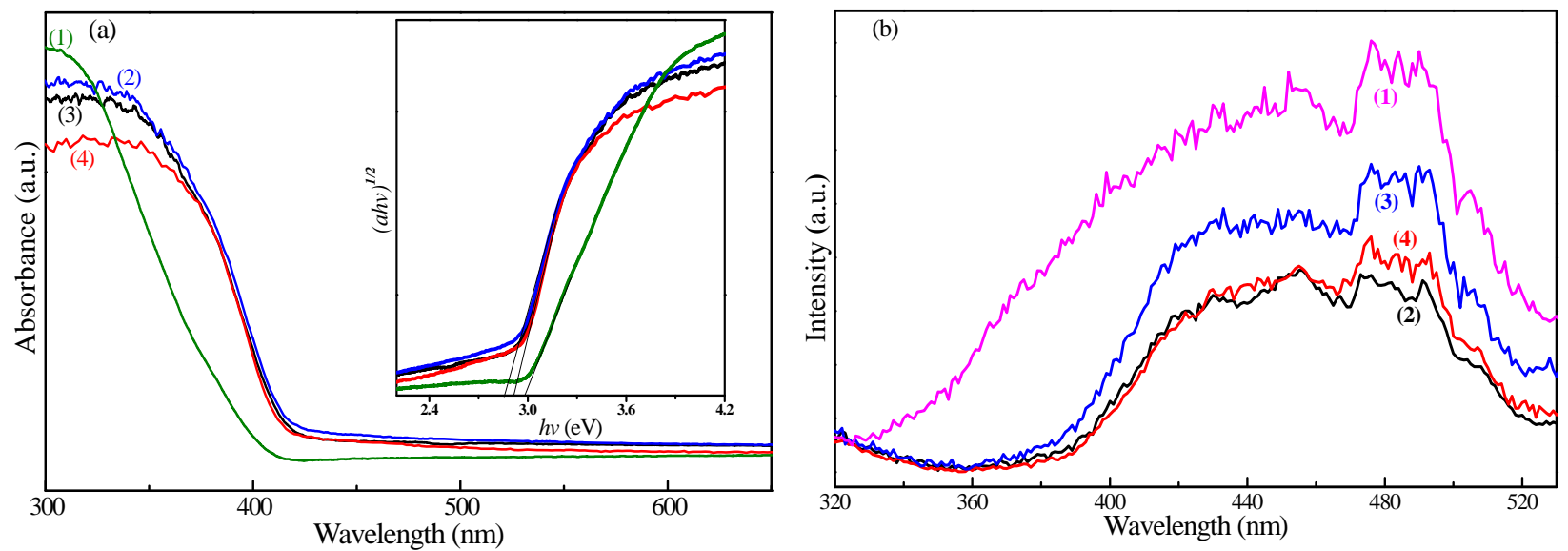

Fig. 5. UV-Vis (a) and PL (b) spectra of $\mathrm{TiO}_{2}$ samples. (1) Undoped $\mathrm{TiO}_{2}$; $\mathrm{TiO}_{2}$ doped with $\mathrm{C}-\mathrm{Y}(2)$, Y (3), and C (4) elements.

absorption under both UV and visible light irradiation. The absorption band edge of $(\mathrm{C}, \mathrm{Y})$-co-doped $\mathrm{TiO}_{2}$ was red shifted to approximately $440 \mathrm{~nm}$. The reason for this red shift is that semiconductor nanomaterials have a large specific surface area, which results in their optical properties being strongly influenced by the surface environment. When a nanoscale semiconductor is modified by materials of different dielectric constants, the optical properties may be changed. This change arises from dielectric confinement effects [40]. Compared with the undoped $\mathrm{TiO}_{2}$, Y oxide has a lower dielectric constant, which relaxes the dielectric confinement effect for the Y-doped $\mathrm{TiO}_{2}$ lattice. Moreover, C-doping modulates the energy shift caused by dielectric confinement effects. These changes evidently had a greater effect on lowering the band gap than the effect of quantum spatial confinement of electron-hole pairs, which increases the band gap. These factors contributed to the red shift in the absorption spectra [41]. When $\mathrm{C}$ and $\mathrm{Y}$ ions incorporated into the $\mathrm{TiO}_{2}$ lattice, the energy band structure of $\mathrm{TiO}_{2}$ was also changed, promoting absorption of visible light.

The PL spectra of $\mathrm{TiO}_{2}$ samples in the range of 320-530 nm are shown in Fig. 5(b). The positions of peaks for both doped and undoped $\mathrm{TiO}_{2}$ showed the same shapes, indicating that doping did not lead to new light-emitting phenomenon but only affected the intensity of the PL spectra. The undoped $\mathrm{TiO}_{2}$ showed a strong and broad emission from 400 to $500 \mathrm{~nm}$. Two PL peaks appeared at 420 and $470 \mathrm{~nm}$. The former may be attributed to band-edge free exciton emission, which depends on radiative recombination of photogenerated electrons and holes at the band gap [42]. The latter likely originates from shallow traps on the surface or bulk defect sites, also known as bound exciton luminescence [43]. The luminous intensity of the doped samples was clearly lower than that of pure $\mathrm{TiO}_{2}$. The luminous intensity of the (C, Y)-co-doped $\mathrm{TiO}_{2}$ was the lowest among all samples. Fluorescence spectra provide information on the capture, migration, and transformation of photogenerated electrons and holes. Thus, a low fluorescence intensity indicates a low recombination probability of photogenerated electrons and holes, which might lead to higher quantum conversion efficiency and better photocatalytic properties. Our PL results suggested that the photocatalytic activity of the samples would decrease in the order: $(\mathrm{C}, \mathrm{Y})$-co-doped $\mathrm{TiO}_{2}>\mathrm{Y}-\mathrm{TiO}_{2}>\mathrm{C}-\mathrm{TiO}_{2}>$ $\mathrm{TiO}_{2}$.

\subsection{Photocatalytic activity}

MB degradation over undoped and doped $\mathrm{TiO}_{2}$ samples was used to evaluate the photocatalytic activity for the investigated samples and the results are shown in Fig. 6. In a blank experiment, no photodegradation of MB was observed in the absence of the catalyst. This result indicates that MB was stable under light illumination. Fig. 6(a) shows that MB removal over the undoped $\mathrm{TiO}_{2}$ was $53.42 \%$ after $3 \mathrm{~h}$ under visible light illumination. All the doped $\mathrm{TiO}_{2}$ catalysts showed better photocatalytic activity than that of undoped $\mathrm{TiO}_{2}$. Notably, the (C, Y)-codoped $\mathrm{TiO}_{2}$ sample featured a marked increase in photocatalytic performance, and achieved 93.59\% degradation within $3 \mathrm{~h}$. The kinetics of the MB photodegradation for the undoped- and doped- $\mathrm{TiO}_{2}$ followed a pseudo-first-order kinetic equation [8]. Fig. $6(\mathrm{~b})$ shows the linear relationship between $\ln \left(C_{0} / C\right)$ and the irradiation time. The value of $k$ was determined from the slope of $\ln \left(C_{0} / C\right)$ plotted versus the corresponding irradiation time. Thus, the value of $k$ indicates the activity of the photocatalyst. For MB photodegradation, the doped $\mathrm{TiO}_{2}$ exhibited rate constants of $0.902 \mathrm{~h}^{-1}$ for the C-Y co-doping, $0.68115 \mathrm{~h}^{-1}$ for the $\mathrm{Y}$ doping, and $0.58403 \mathrm{~h}^{-1}$ for the $\mathrm{C}$-doping, which were $3.5,2.6$, and 2.3 times as high as that for the undoped $\mathrm{TiO}_{2}$ $\left(0.25586 \mathrm{~h}^{-1}\right)$, respectively. The activity of commercial P25 showed equivalent performance to that of undoped $\mathrm{TiO}_{2}$ (Fig. 6(a)), indicating that the mixed phase co-doped $\mathrm{TiO}_{2}$ samples are highly effective photocatalysts. The rate constants of the MB photodegradation were clearly enhanced by the C- and Y-doping.

The factors contributing to this enhancement were as follows. (1) The (C, Y)-co-doping broadened the response to visible light and inhibited recombination of photogenerated hole-electron pairs (Fig. 5(a)). The UV-Vis spectra of the doped $\mathrm{TiO}_{2}$ samples were red shifted compared with those for pure $\mathrm{TiO}_{2}$. (2) The average crystallite size of the (C, Y)-co-doped $\mathrm{TiO}_{2}$ sample was smaller than that of single doped samples, which suggests a larger specific surface area and more active centers. 

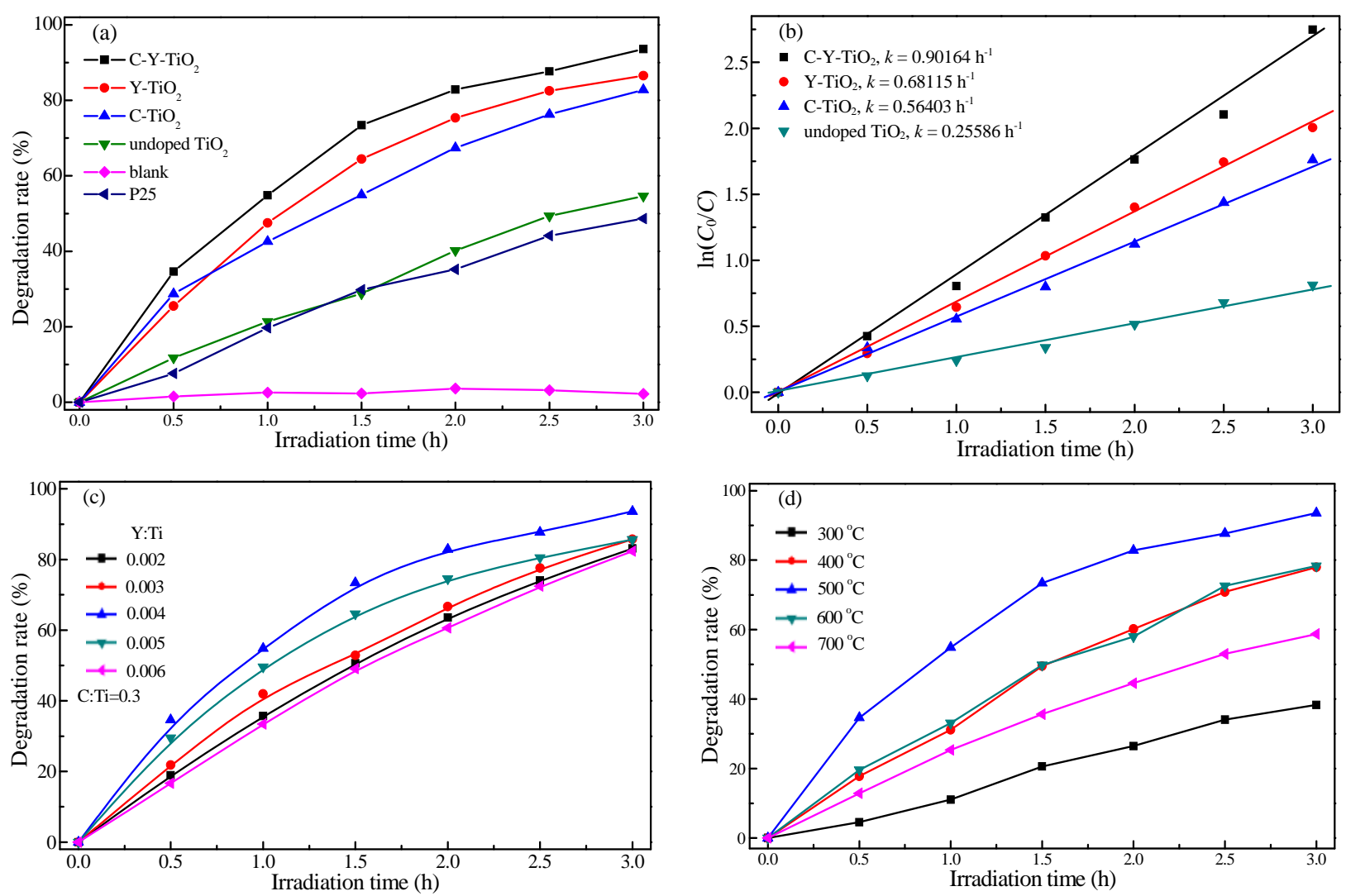

Fig. 6. Time course (a) and kinetic curves (b) of $\mathrm{MB}$ photodegradation over different samples (undoped $\mathrm{TiO}_{2} ; \mathrm{Y}-\mathrm{TiO}_{2}, M_{\mathrm{Y}} / M_{\mathrm{Ti}}=0.004 ; \mathrm{C}-\mathrm{TiO} \mathrm{O}_{2}, M_{\mathrm{C}} / M_{\mathrm{Ti}}=$ 0.3; (C, Y)-co-doped $\mathrm{TiO}_{2}, M_{\mathrm{C}}: M_{\mathrm{Y}}: M_{\mathrm{Ti}}=0.3: 0.004: 1$; and commercial P25) under visible light irradiation. Time course of MB photodegradation over the samples of $(\mathrm{C}, \mathrm{Y})$-co-doped $\mathrm{TiO}_{2}$ with different Y-doping concentrations (c) and treated at different temperatures $\left(M_{\mathrm{C}}: M_{\mathrm{Y}}: M_{\mathrm{Ti}}=0.3: 0.004: 1\right)(\mathrm{d})$.

This effect would be beneficial for the photocatalytic activity. A larger specific surface area enables more molecules to adsorb to the $\mathrm{TiO}_{2}$ surface in the photocatalytic system. The smaller crystallite size might also contribute to more rapid transfer of photogenerated electrons and holes to the surface of the $\mathrm{TiO}_{2}$. (3) The C- and Y-doping also affected the separation efficiency of electron-hole pairs contributing to the higher photocatalytic activity of $\mathrm{TiO}_{2}$. The (C, Y)-co-doped $\mathrm{TiO}_{2}$ sample with the ratio of $M_{\mathrm{C}}: M_{\mathrm{Y}}: M_{\mathrm{Ti}}=0.3: 0.004: 1$ showed the highest photocatalytic rate (Fig. 6(c)). Optimal doping of $\mathrm{C}$ and $\mathrm{Y}$ can promote the separation of the photogenerated electron/hole pairs. (4) The effects of anatase and rutile might also contribute to the high photocatalytic activity [19]. The proportion of each phase in $\mathrm{TiO}_{2}$ was investigated by changing the annealing temperature and $\mathrm{Y}$ content. The photocatalytic activities of these (C, Y)-codoped $\mathrm{TiO}_{2}$ sample are presented in Fig. 6(c) and (d). Thus, control over the proportions of anatase-rutile phases can improve the photocatalytic performance of $\mathrm{TiO}_{2}$.

\section{Conclusions}

Crystalline mixed phase $\mathrm{TiO}_{2}$ photocatalysts doped with different $\mathrm{C}$ and $\mathrm{Y}$ contents were successfully prepared by a sol-gel process and characterized by different techniques. The incorporation of $\mathrm{C}$ into the $\mathrm{TiO}_{2}$ lattice accelerated the phase transition from anatase to rutile, while $\mathrm{Y}$ inhibited the ana- tase-rutile transformation and promoted a smaller $\mathrm{TiO}_{2}$ grain size. Both $\mathrm{C}$ and $\mathrm{Y}$ doping broadened the absorption spectrum to the visible light region and inhibited recombination of the photogenerated electron/hole pairs. The combined effects of the co-doped $\mathrm{C}$ and $\mathrm{Y}$ ions enhanced the photocatalytic activity compared with that of the undoped and mono-doped $\mathrm{TiO}_{2}$. The optimum preparation parameters were determined to be $\mathrm{C}$ and $\mathrm{Y}$ ions doping contents of $\mathrm{C}: \mathrm{Y}: \mathrm{Ti}=0.30: 0.004: 1$ (reactant molar ratio) with sintering at $500{ }^{\circ} \mathrm{C}$ for $4 \mathrm{~h}$. The photocatalytic $\mathrm{MB}$ degradation rate of the sample prepared under the optimum conditions was $93.59 \%$ over $3 \mathrm{~h}$. The first-order apparent rate constant of the optimum catalyst was approximately $3.5,2.6$, and 2.3 times as high as those of the undoped $\mathrm{TiO}_{2}, \mathrm{C}-\mathrm{TiO}_{2}$ and $\mathrm{Y}-\mathrm{YiO}_{2}$, respectively, under the same experimental conditions.

\section{Acknowledgments}

We thank Andrew Jackson, PhD, from Liwen Bianji, Edanz Group China (www.liwenbianji.cn/ac), for editing the English text of a draft of this manuscript.

\section{References}

[1] M. Tanveer, G. Tezcanli Guyer, Renew. Sust. Energ. Rev., 2013, 24, 534-543.

[2] J. W. Tang, J. R. Durrant, D. R. Klug, J. Am. Chem. Soc., 2008, 130, 


\section{Graphical Abstract}

Chin. J. Catal., 2017, 38: 1688-1696 doi: 10.1016/S1872-2067(17)62893-6

Influence of carbon and yttrium co-doping on the photocatalytic activity of mixed phase $\mathrm{TiO}_{2}$

Honglin Gao, Jianmei Liu, Jin Zhang, Zhongqi Zhu, Genlin Zhang, Qingju Liu*

Yunnan University
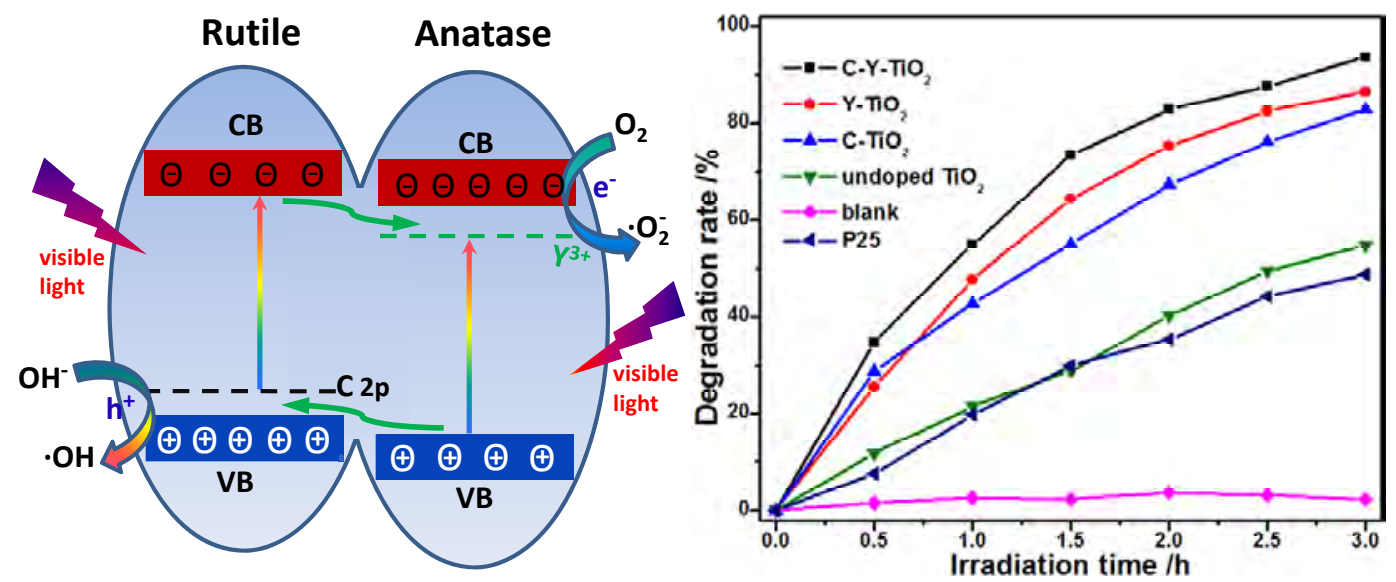

Carbon and Yttrium co-doping mixed phase $\mathrm{TiO}_{2}$ has been fabricated by sol-gel method. The enhancement of photocatalytic activity can be attributed to the synergistic effect of $\mathrm{C}$ and $\mathrm{Y}$ co-doping and the appropriate crystalline structure.

13885-13891.

[3] S. Deki, K. Kuratani, M. Uemura, K. Akamatsu, M. Mizuhata, A. Kajinami, Thin Solid Films, 2004, 460, 83-86.

[4] A. Di Paola, G. Marci, L. Palmisano, M. Schiavello, K. Uosaki, S. Ikeda, B. Ohtani, J. Phys. Chem. B, 2002, 106, 637-645.

[5] H. G. Peng, J. W. Ying, J. Y. Zhang, X. H. Zhang, C. Peng, C. Rao, W. M. Liu, N. Zhang, X. Wang, Chin. J. Catal., 2017, 38, 39-47.

[6] S. Khanchandani, S. Kumar, A. K. Ganguli, ACS Sustain. Chem. Eng., 2016, 4, 1487-1499.

[7] P. Wang, J. Wang, T. S. Ming, X. F. Wang, H. G. Yu, J. G. Yu, Y. G. Wang, M. Lei, ACS Appl. Mater. Inter., 2013, 5, 2924-2929.

[8] F. C. Peng, H. L. Gao, G. L. Zhang, Z. Q. Zhu, J. Zhang, Q. J. Liu, Materials, 2017, 10, 209.

[9] M. J. Mattle, K. R. Thampi, Appl. Catal. B, 2013, 140-141, 348-355.

[10] Y. T. Lin, C. H. Weng, Y. H. Lin, C. C. Shiesh, F. Y. Chen, Sep. Purif. Technol., 2013, 116, 114-123.

[11] M. E. Hassan, L. C. Cong, G. L. Liu, D. W. Zhu, J. B. Cai, Appl. Surf. Sci,, 2014, 294, 89-94.

[12] K. A. Saharudin, S. Sreekantan, C. W. Lai, Mater. Sci. Semicond. Process., 2014, 20, 1-6.

[13] J. Reszczyńska, T. Grzyb, J. W. Sobczak, W. Lisowski, M. Gazda, B. Ohtani, A. Zaleska, Appl. Catal. B, 2015, 163, 40-49.

[14] Y. J. Wang, K. C. Lu, C. G. Feng, J. Rare Earth., 2011, 29, 866-871.

[15] H. Y. Wei, Y. S. Wu, N. Lun, F. Zhao, J. Mater. Sci., 2004, 39, 1305-1308.

[16] H. Q. Jiang, Q. F. Wang, S. Y. Li, J. S. Li, Q. Y. Wang, Chin. J. Catal., 2014, 35, 1068-1077.

[17] D. O. Scanlon, C. W. Dunnill, J. Buckeridge, S. A. Shevlin, A. J. Logsdail, S. M. Woodley, C. R. A. Catlow, M. J. Powell, R. G. Palgrave, I. P. Parkin, G. W. Watson, T. W. Keal, P. Sherwood, A. Walsh, A. A. Sokol, Nat. Mater., 2013, 12, 798-801.

[18] Z. Luo, A. S. Poyraz, C. H. Kuo, R. Miao, Y. Meng, S. Y. Chen, T. Jiang, C. Wenos, S. L. Suib, Chem. Mater., 2015, 27, 6-17.
[19] X. L. Wang, S. Shen, Z. C. Feng, C. Li, Chin. J. Catal., 2016, 37, 2059-2068.

[20] Y. Mi, Y. X. Weng, Sci Rep., 2015, 5, 11482.

[21] D. Y. Zhang, M. N. Yang, S. Dong, Phys. Chem. Chem. Phys., 2015, 17, 29079-29084.

[22] Y. Chimupala, P. Junploy, T. Hardcastle, A. Westwood, A. Scott, B. Johnson, R. Brydson, J. Mater. Chem. A, 2016, 4, 5685-5699.

[23] L. Li, C. Y. Liu, Y. Liu, Mater. Chem. Phys., 2009, 113, 551-557.

[24] Q. Li, R. C. Xie, Y. W. Li, E. A. Mintz, J. K. Shang, Environ. Sci. Technol., 2007, 41, 5050-5056.

[25] S. Y. Chen, C. C. Ting, W. F. Hsieh, Thin Solid Films, 2003, 434, 171-177.

[26] J. Striova, C. Lofrumento, A. Zoppi, E. M. Castellucci, J. Raman Spectrosc., 2006, 37, 1139-1145.

[27] S. Triebold, G. L. Luvizotto, R. Tolosana-Delgado, T. Zack, H. Von Eynatten, Contrib. Mineral. Petr., 2011, 161, 581-596.

[28] Z. G. Lu, C. T. Yip, L. P. Wang, H. T. Huang, L. M. Zhou, ChemPlusChem, 2012, 77, 991-1000.

[29] A. Li Bassi, D. Cattaneo, V. Russo, C. E. Bottani, E. Barborini, T. Mazza, P. Piseri, P. Milani, F. O. Emst, K. Wegner, S. E. Pratsinis, J. Appl. Phys., 2005, 98, 074350.

[30] G. A. Tompsett, G. A. Bowmaker, R. P. Cooney, J. B. Metson, K. A. Rodgers, J. M. Seakins, J. Raman Spectrosc., 1995, 26, 57-62.

[31] D. Bersani, P. P. Lottici, X. Z. Ding, Appl. Phys. Lett., 1998, 72, 73-75.

[32] S. Balaji, Y. Djaoued, J. Robichaud, J. Raman Spectrosc., 2006, 37, 1416-1422.

[33] S. G. Ullattil, P. Periyat, J. Mater. Chem. A, 2016, 4, 5854-5858.

[34] V. V. Atuchin, V. G. Kesler, N. V. Pervukhina, Z. M. Zhang, J. Electron. Spectrosc. Related Phenomena, 2006, 152, 18-24.

[35] D. W. Kwon, P. W. Seo, G. J. Kim, S. C. Hong, Appl. Catal. B, 2015, 163, 436-443.

[36] X. He, J. J. Wang, Z. Shu, A. D. Tang, H. M. Yang, RSC Adv., 2016, 6, 
41765-71771.

[37] Y. B. Yan, Y. L. Yu, C. Cao, S. L. Huang, Y. J. Yang, X. D. Yang, Y. A. Cao, CrystEngComm, 2016, 18, 2956-2964.

[38] Y. Huang, W. Ho, S. Lee, L. Z. Zhang, G. S. Li, J. C. Yu, Langmuir, 2008, 24, 3510-3516.

[39] J. G. Yu, G. P. Dai, Q. J. Xiang, M. Jaroniec, J. Mater. Chem., 2011, 21, 1049-1059.

[40] S. Hayashi, R. Koh, Y. Ichiyama, K. Yamamoto, Phys. Rev. Lett.,
1988, 60, 1085-1088.

[41] J. W. Cen, X. J. Li, M. X. He, S. J. Zheng, M. Z. Feng, J. Chin. Rare Earth. Soc., 2005, 23, 668-673.

[42] N. D. Abazovic, M. I. Comor, M. D. Dramicanin, D. J. Jovanovic, S. P. Ahrenkiel, J. M. Nedeljkovic, J. Phys. Chem. B, 2006, 110, 25366-25370.

[43] A. Stevanovic, M. Bttner, Z. Zhang, J. T. Yates, J. Am. Chem. Soc., 2012, 134, 324-332.

\title{
碳和钇共掺杂对混相 $\mathrm{TiO}_{2}$ 光催化性能的影响
}

\author{
高洪林, 刘健梅, 张瑾, 朱忠其, 张艮林, 柳清菊* \\ 云南大学材料科学与工程学院, 云南省微纳材料与技术重点实验室, 云南昆明 650091
}

\begin{abstract}
摘要: $\mathrm{TiO}_{2}$ 因其毒性低、稳定性高、制备成本低廉而获得广泛应用,特别是作为光催化剂在降解环境污染物方面受到了广 泛关注; 然而, 纯 $\mathrm{TiO}_{2}$ 较大的光生载流子复合率和较宽的带隙限制了其应用. 元素掺杂作为一种拓宽光催化剂光吸收能力 的方法广泛应用于各种光催化剂的修饰改性, 而两种具有光催化性能的 $\mathrm{TiO}_{2}$ 相共存则能有效抑制光生载流子的复合, 因此 采取合适的方法有效利用这两种 $\mathrm{TiO}_{2}$ 改性的方法制备得到更具实际应用潜质的光催化剂具有一定的可行性.

本文通过简单的溶胶-凝胶过程向锐钛矿相与金红石相组成的混相 $\mathrm{TiO}_{2}$ 中共掺杂碳和钎得到了一种活性较高的可见 光响应光催化剂. 采用粉末 $X$ 射线衍射、拉曼光谱、X射线光电子能谱和透射电镜等表征手段研究了碳和钎掺杂对 $\mathrm{TiO}_{2}$ 结 构的影响, 发现碳掺杂有利于金红石相的形成且材料具有更大的晶粒尺寸, 钎掺杂则有利于锐钛矿相的形成且能细化材料 的晶粒尺寸, 提高材料的比表面积, 导致材料更好的光催化活性. 材料在 $30 \mathrm{~W}$ 苂光灯光照条件下的光催化降解亚甲基蓝 (MB) 性能的研究显示, C-Y- $\mathrm{TiO}_{2}$ 样品具有比单掺杂和未掺杂样品更高的光催化活性, 其顺序为C-Y- $\mathrm{TiO}_{2}>\mathrm{Y}-\mathrm{TiO}_{2}>\mathrm{C}-\mathrm{TiO}_{2}>$ $\mathrm{TiO}_{2} \approx \mathrm{P} 25$. 此外, 降解反应动力学研究表明C-Y- $-\mathrm{TiO}_{2}$ 样品光降解MB的速率是未掺杂样品在相同条件下降解速率的3.5倍. 不同钎掺杂含量样品的结构和光催化降解MB的研究结果表明, 钎掺杂显著促进了锐铁矿相 $\mathrm{TiO}_{2}$ 的形成. 这说明钇可能仅 掺杂进入锐钛矿相, 因此合适的钎掺杂量才能有效形成最优化的光催化性能的混相 $\mathrm{TiO}_{2}$. 不同热处理温度下获得的样品的 光降解MB特性也表明,一定的热处理温度有利于合适的锐钛矿相和金红石相的组成, 从而有利于相间的协同效应. 紫外-可 见光谱和荧光光谱表征分析表明, 碳和钎的掺杂都拓展了其吸收光谱到可见光区域, 且抑制了光生电子和空穴对的复合, 进 而提高了材料的光催化活性. 碳和钎共掺杂的混相 $\mathrm{TiO}_{2}$ 具有较高可见光光催化活性的主要原因有两个方面: 一是元素掺杂 减小了 $\mathrm{TiO}_{2}$ 的带隙使得材料具有可见光响应; 二是金属和非金属元素在锐铁矿相与金红石相 $\mathrm{TiO}_{2}$ 中不同的掺杂特性形成 的协同效应,抑制了光生电子和空穴的复合.
\end{abstract}

关键词: 二氧化钛; 共掺杂; 混相; 相控制; 可见光光催化

收稿日期: 2017-05-31. 接受日期: 2017-07-30. 出版日期: 2017-10-05.

*通讯联系人. 电话/传真: (0871)65035376; 电子信箱: qjiliu@ynu.edu.cn

基金来源：国家高技术研究发展计划(863计划, 2015AA034601); 云南省自然科学基金(2016FB084); 云南省教育厅科学研究基金 重点项目(2015Z003); 云南省微纳材料与技术重点实验室开放基金(ZZ2016006).

本文的英文电子版由Elsevier出版社在ScienceDirect上出版(http://www.sciencedirect.com/science/journal/18722067). 